Article

\title{
Antiviral and Cytotoxic Activity of Different Plant Parts of Banana (Musa spp.)
}

\author{
Sujogya Kumar Panda ${ }^{1,2}, * \mathbb{E}$, Ana Hortência Fonsêca Castro ${ }^{1,3} \mathbb{0}$, Ramin Saleh Jouneghani ${ }^{1}$, \\ Pieter Leyssen ${ }^{4}$, Johan Neyts ${ }^{4}\left(\mathbb{D}\right.$, Rony Swennen ${ }^{5,6,7}$ (D) and Walter Luyten ${ }^{1}(\mathbb{D}$ \\ 1 Department of Biology, Katholieke Universiteit Leuven, 3000 Leuven, Belgium; \\ acastro905@gmail.com (A.H.F.C.); r.saleh.j@gmail.com (R.S.J.); walter.luyten@kuleuven.be (W.L.) \\ 2 Mayurbhanj Biological Research (MBR), Bhanjpur, Baripada 757002, Odisha, India \\ 3 Plant Physiology and Biochemistry, Universidade Federal de São João Del-Rei, Av. Sebastião Gonçalves \\ Coelho, 400-Chanandour, Divinópolis MG 35501-296, Brazil \\ 4 Rega Institute for Medical Research, Laboratory of Virology and Chemotherapy, Katholieke Universiteit \\ Leuven, 3000 Leuven, Belgium; pieter.leyssen@kuleuven.be (P.L.); johan.neyts@kuleuven.be (J.N.) \\ 5 International Institute of Tropical Agriculture, Arusha P.O. Box 447, Tanzania; rony.swennen@kuleuven.be \\ 6 Laboratory of Tropical Crop Improvement, Division of Crop Biotechnics, Katholieke Universiteit Leuven, \\ 3001 Leuven, Belgium \\ 7 Bioversity International, 3001 Leuven, Belgium \\ * Correspondence: sujogya.panda@kuleuven.be; Tel.: +32-16-373467
}

Received: 13 April 2020; Accepted: 13 May 2020; Published: 15 May 2020

check for updates

\begin{abstract}
Chikungunya and yellow fever virus cause vector-borne viral diseases in humans. There is currently no specific antiviral drug for either of these diseases. Banana plants are used in traditional medicine for treating viral diseases such as measles and chickenpox. Therefore, we tested selected banana cultivars for their antiviral but also cytotoxic properties. Different parts such as leaf, pseudostem and corm, collected separately and extracted with four different solvents (hexane, acetone, ethanol, and water), were tested for in vitro antiviral activity against Chikungunya virus (CHIKV), enterovirus 71 (EV71), and yellow fever virus (YFV). Extracts prepared with acetone and ethanol from leaf parts of several cultivars exhibited strong $\left(\mathrm{EC}_{50}\right.$ around $\left.10 \mu \mathrm{g} / \mathrm{mL}\right)$ anti-CHIKV activity. Interestingly, none of the banana plant extracts (concentration 1-100 $\mu \mathrm{g} / \mathrm{mL}$ ) were active against EV71. Activity against YFV was restricted to two cultivars: Namwa Khom-Pseudostem-Ethanol $(5.9 \pm 5.4)$, Namwa Khom-Corm-Ethanol $(0.79 \pm 0.1)$ and Fougamou-Corm-Acetone $(2.5 \pm 1.5)$. In most cases, the cytotoxic activity of the extracts was generally 5- to 10-fold lower than the antiviral activity, suggesting a reasonable therapeutic window.
\end{abstract}

Keywords: banana plant extracts; Chikungunya virus; cytotoxicity; enterovirus 71; yellow fever virus

\section{Introduction}

Banana (Musa spp.) is a perennial herb that produces the second-most important fruit after citrus. Currently, worldwide banana production is over 144 million tonnes annually and includes dessert and cooking bananas [1]. More than 1000 genotypes exist, derived from intra- or inter-specific hybridizations of the wild diploid $(2 \mathrm{n}=2 \mathrm{x}=22$ chromosomes) ancestral species M. acuminata Colla (A genome) and M. balbisiana Colla (B genome) [2]. The edible bananas are parthenocarpic, with the following groups: diploids (AA, AB, possibly BB), triploids (AAA, AAB, ABB, possibly BBB), or tetraploids (AAAA, AAAB, AABB, ABBB). Sweet bananas are widely cultivated on all continents except Antarctica. They include AA (Pisang Mas-Amas, Kluai Khai, Bocadillo, Figue sucree, sucrier), AAA (Cavendish-Giant and Dwarf, Grande Naine, Poyo, Robusta), and AAB (Silk, Mysore-Inangel, Pisang Keling, Prata, Pacovan, Prata Ana). Cooking bananas are also important and belong to the ABB 
group and possibly BBB. Important cultivars are Saba, Cachaco, Pisang Awak, Pelipita, and Cardaba [3]. There is ample evidence that banana plants contain (poly)phenolic compounds [4] and carotenoids ( $\alpha$-carotene, trans- $\beta$-carotene, lutein, 13-cis- $\beta$-carotene and 9 -cis- $\beta$-carotene) $[5,6]$, which are useful in the treatment of multiple diseases [7]. The banana pulp and peel contain carbohydrates, minerals (K, $\mathrm{P}$, $\mathrm{Ca}, \mathrm{Mg}, \mathrm{Mn}$ and $\mathrm{Zn}$ ), antioxidants, vitamins (C, A and E), catecholamines, as well as pyridoxine [6-8].

Plantains as well as dessert bananas, and the other parts of the Musa spp. plant, which include roots, corm (i.e., underground stem), pseudostem (i.e., aboveground false stem), leaves, flowers, and peels, have long been used in traditional medicine around the world to treat fevers, burns, liver problems, diarrhea, inflammation, pain, snakebite, and diabetes [9-11]. Ethnopharmacological studies have documented several traditional uses of bananas, and different plant parts (flower, leaves, pseudostem, corm, fruit pulp and peels) have been studied for their anti-ulcerogenic [12], hypolipidemic [13], hypoglycemic [14], and wound-healing activity [15]. BanLec, a jacalin-related lectin, was found to be a potent inhibitor of HIV replication [16]. Later, Swanson and coworkers demonstrated that "a single amino-acid substitution in a banana lectin, replacing histidine84 with threonine, significantly reduces its mitogenicity, while preserving its broad-spectrum antiviral potency" [17]. Except for that study, to the best of our knowledge, no scientific study on antiviral properties of Musa has been reported. Therefore, we studied the antiviral (and also cytotoxic) properties of different parts of 10 dessert or cooking banana plants.

\section{Materials and Methods}

\subsection{Collection of Samples}

Leaves, pseudostems and corms of 10 adult banana cultivars were collected in March 2015 from the tropical greenhouses, KU Leuven, Heverlee Campus (Leuven Belgium), and one variety was obtained from Africa (Table 1). The greenhouse plants were grown in DCM pot soil type 7.

Table 1. List and characteristics of banana cultivars studied for antiviral activity.

\begin{tabular}{ccccc}
\hline ITC & Cultivar & Genome & Subgroup & DArT \\
\hline ITC0767 & Dole & ABB & Bluggoe & Other ABB \\
ITC0643 & Cachaco & ABB & Bluggoe & Musa balbisiana \\
ITC1138 & Saba & ABB & Saba & Other ABB \\
ITC0652 & Kluai Tiparot & ABB & unknown & Musa balbisiana \\
ITC0472 & Pelipita & ABB & unknown & Other ABB \\
ITC0659 & Namwah Khom & ABB & Pisang Awak & Pisang Awak \\
ITC0101 & Fougamou & ABB & Pisang Awak & Pisang Awak \\
ITC0654* & Petite Naine & AAA & Cavendish & AAA Cavendish \\
ITC0346 & Giant Cavendish & AAA & Cavendish & AAA Cavendish \\
ITC1356 & Mbwazirume & AAA & Mutika/Lujugira & AAAh \\
\hline
\end{tabular}

* From Africa, all others collected from the Laboratory of Tropical Crop Improvement greenhouse, Leuven, DArT-Diversity Array Technology [18].

\subsection{Extraction Preparation}

The plant parts (e.g., leaves, pseudostems and corms) were cut into small slices and dried in an oven at $70^{\circ} \mathrm{C}$. All samples were then ground to a fine powder using a high-powered HK-10B plant mill (Guangzhou Xulang Machinery \& Equipment Co. Ltd., Guangzhou, China). Afterwards, the powdered samples were stored completely dried in a cold room at $4{ }^{\circ} \mathrm{C}$ to avoid growth of fungi, molds, bacteria or other microorganisms [19]. One gram of the fine plant powder was extracted in $15 \mathrm{~mL}$ conical Falcon tubes with screwcaps using $10 \mathrm{~mL}$ of four different solvents (hexane, acetone, ethanol, and water) at ambient temperature with the aid of sonication $(4 \times 15$ min over a $24 \mathrm{~h}$ period $)$ in a water bath (Branson) and repeated vortexing. After 1 day, the tubes were centrifuged for $10 \mathrm{~min}$ at 3500x $g$, and the supernatant transferred in $1 \mathrm{~mL}$ aliquots to tubes (Abgene ${ }^{\mathrm{TM}} 2 \mathrm{D}$ barcoded $2 \mathrm{~mL}$ screw cap 
storage tubes, Thermo Scientific ${ }^{\mathrm{TM}}$, Geel, Belgium). After evaporation of water and ethanol in a Savant SpeedVac Concentrator (Thermo Scientific ${ }^{\mathrm{TM}}$, Geel, Belgium), and acetone and hexane evaporation at ambient temperature in a chemical fume hood, the dry weight of each sample was determined. A final stock concentration in DMSO $(10 \mathrm{mg} / \mathrm{mL})$ of each sample was prepared after drying. The samples were stored at $4{ }^{\circ} \mathrm{C}$ until further testing.

\subsection{Antiviral Test}

Antiviral activity was tested as described earlier [20-22]. Three different viruses were used: Chikungunya virus (CHIKV) (899 strain) propagated in Vero cells subtype A, enterovirus 71 (EV71) (BRCR strain) cultured in human rhabdomyosarcoma (RD) cells, and yellow fever virus (YFV) (17D Stamari 1 strain) cultured in human liver (Huh) cells subtype 7. The final, maximal DMSO concentration in the assay wells with the highest sample input (1\%) was well tolerated by the cells. Favipiravir, rupintrivir and $2^{\prime}, 5^{\prime}$-bis-O-trityl uridine were used as a positive control for CHIKV, EV71 and YFV, respectively. Plant extracts that showed antiviral activity were also evaluated for cytotoxicity by the MTS (3-(4,5-dimethylthiazol-2-yl)-5-(3-carboxymethoxyphenyl)-2-(4-sulfophenyl)-2H-tetrazolium) method. Briefly, the same experimental set-up was used as for the antiviral assay, except that uninfected cultures were incubated with a serial dilution of plant extract for 3 days at $37^{\circ} \mathrm{C}$, then stained with MTS. Results were expressed as $\mathrm{EC}_{50}$ and $\mathrm{CC}_{50}$. The cytotoxic concentration was calculated as the $\mathrm{CC}_{50}$, or the concentration of plant extract required to reduce cell proliferation by $50 \%$ relative to the number of cells in the solvent-treated controls. The formula used to calculate cytotoxic activity was cytopathic effect $(\mathrm{CPE}) \%=\left(\mathrm{ODCc}-\mathrm{OD}_{\text {plant extract }}\right) / \mathrm{OD}_{\mathrm{CC}}$, where ODcc corresponds to the optical density of the uninfected and untreated cell cultures and $\mathrm{OD}_{\text {plant extract }}$ corresponds to the OD of uninfected cultures, treated with the extract. In addition, the selectivity index (SI) was calculated as the ratio of the $\mathrm{CC}_{50}$ for cell growth to the antiviral $\mathrm{EC}_{50}\left(\mathrm{CC}_{50} / \mathrm{EC}_{50}\right) . \mathrm{SS}=$ Selectivity Surface (integrated surface delineated by the $\mathrm{EC}_{50}$ curve, the $\mathrm{CC}_{50}$ curve and the $50 \%$ horizontal). Therapeutic Index (TI) is defined as $\mathrm{SS} \times$ $10 \log S I[20]$.

\subsection{Thin-Layer Chromatography (TLC) and Determination of Total Phenolic Content (TPC)}

Phytochemical analysis by means of TLC was carried out for selected crude extracts, as previously described by Panda et al. [23]. The TLC plate (dimensions $2.5 \times 7.5 \mathrm{~cm}$, coated with silica gel 60 F254, Merck, Darmstadt, Germany) was developed with methanol:dichloromethane (9:1, v/v), methanol:dichloromethane $(1: 1, v / v)$, methanol:dichloromethane $(1: 9, v / v)$, hexane:ethyl acetate $(1: 3, v / v)$, hexane:ethyl acetate $(1: 1, v / v)$, and hexane:ethyl acetate $(3: 1, v / v)$ at ambient temperature (approximately $20^{\circ} \mathrm{C}$ ), and dried in an oven at $90^{\circ} \mathrm{C}$ for $5 \mathrm{~min}$ to evaporate the solvent. The plate was visualized under ultra-violet (UV) light at (254 and $360 \mathrm{~nm})$. Later, the same plate was used for visualization of the spots by spraying with $5 \%$ sulphuric acid in ethanol, followed by heating at $100{ }^{\circ} \mathrm{C}$ for $5 \mathrm{~min}$. Phytochemicals were tentatively identified by comparison of Rf values and spot colours with literature data. The TPC was estimated using the Folin-Ciocalteu's reagent according to the method described in Jouneghani et al. [24].

\subsection{Statistical Analysis}

The experimental results were expressed as an average of three replicates. Extracts showing interesting properties under the microscope (cell morphology was examined for minor signs of CPE or for adverse effects) were repeated three times. Heat maps were constructed using ClustVis: a web tool for visualizing clustering of multivariate data (BETA) (https://biit.cs.ut.ee/clustvis/). Further, dendrograms were constructed of the genetic relationship between the banana plant cultivars, based on Unweighted Pair Group Method with Arithmetic Mean (UPGMA) analyses [25]. For more information on genetic relationship between the cultivars, see Christelová et al. [26]. 


\section{Results}

None of the banana plant extracts were active against EV71 in the viral CPE reduction assay (Supplementary Material I, Figure S1).

\subsection{Activity of Extracts against CHIKV}

None of aqueous extracts was active against CHIKV. Extracts that show prominent antiviral activity against CHIKV are presented in Figure 1 (see also Supplementary Material II, Figure S2, Table 2). The $\mathrm{EC}_{50}$ varied with the solvent used to prepare an extract ( $\sim 6$ to $47 \mu \mathrm{g} / \mathrm{mL}$ ). Unexpectedly, the $\mathrm{EC}_{50}$ values cluster in three groups: $5-15 \mu \mathrm{g} / \mathrm{mL}, 34-47 \mu \mathrm{g} / \mathrm{mL}$, and inactive (Figure 2a). Possibly the activity is due to a single compound, which is present at a high or a low concentration, or absent altogether. The $\mathrm{CC}_{50}$ did not correlate with the $\mathrm{EC}_{50}$ values of the same extract, suggesting that the antiviral compound is different from the one(s) causing cytotoxicity.

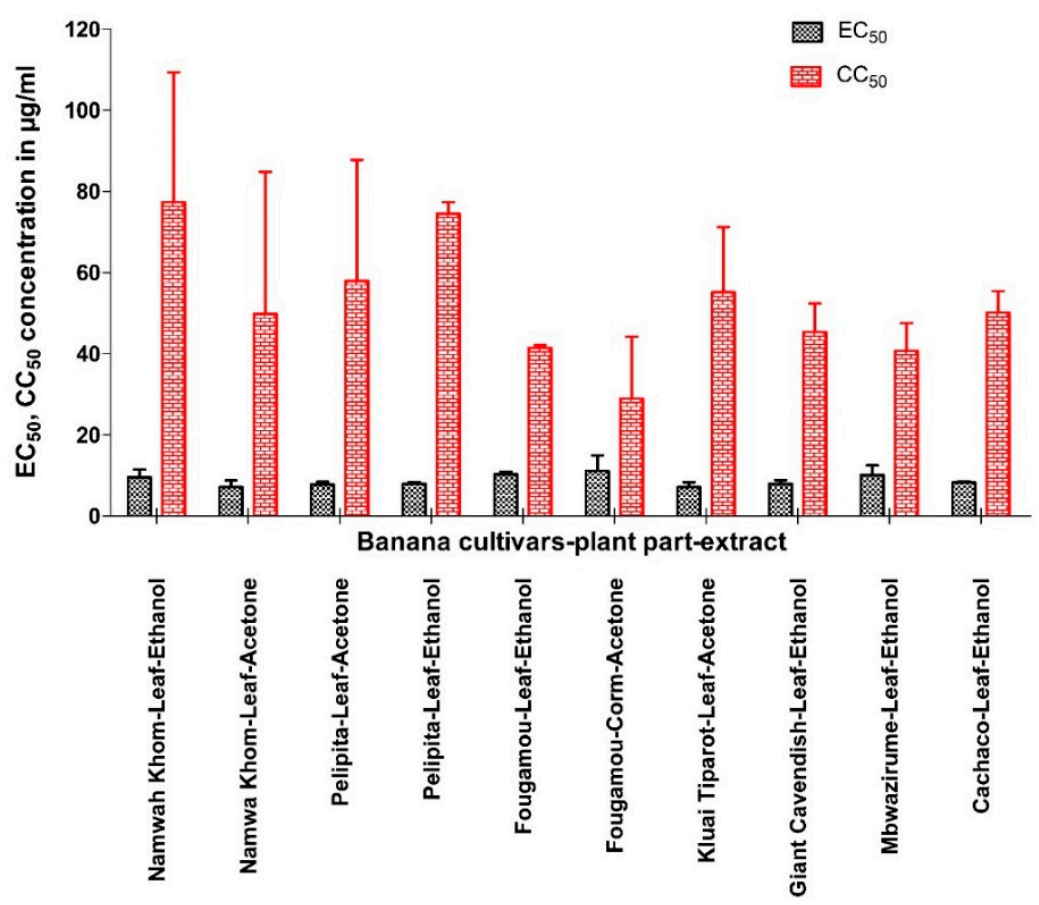

Figure 1. Comparison of $\mathrm{EC}_{50}$ and $\mathrm{CC}_{50}($ mean $\pm \mathrm{SD})$ of selected banana cultivars-plant part-extract against Chikungunya virus.

Table 2. Antiviral and cytotoxic activity of banana varieties against Chikungunya virus.

\begin{tabular}{lcccccccccc}
\hline Code No. & Variety & Parts Used & $\begin{array}{c}\text { Extract } \\
\text { Tested }\end{array}$ & $\begin{array}{c}\mathbf{E C}_{50} \\
(\mu \mathrm{g} / \mathrm{mL})\end{array}$ & $\begin{array}{c}\mathbf{E C}_{\mathbf{9 0}}(\mu \mathrm{g} / \mathrm{mL}) \\
\text { Maximum } \\
\text { Inhibition }\end{array}$ & $\begin{array}{c}\mathbf{C C}_{\mathbf{5 0}} \\
(\mu \mathrm{g} / \mathrm{mL})\end{array}$ & SI & SS & TI \\
\hline BAVARIE1_001 & Saba & Leaf & Acetone & 7.88 & 12.6 & 72.2 & 23.2 & 2.94 & 5.05 & 2.36 \\
\hline BAVARIE1_003 & Saba & Corm & Acetone & 36.3 & - & 73.3 & 100 & 2.76 & 5.13 & 2.26 \\
\hline BAVARIE1_004 & Pelipita & Leaf & Acetone & 7.21 & - & 80.6 & 38.1 & 5.28 & 11 & 7.97 \\
\hline BAVARIE1_005 & Pelipita & Pseudostem & Acetone & 41.2 & - & 69.9 & 69 & 1.67 & 0.026 & 0.006 \\
\hline BAVARIE1_006 & Pelipita & Corm & Acetone & 38.9 & - & 71 & 100 & 2.57 & 4.31 & 1.77 \\
\hline BAVARIE1_007 & Kluai Tiparot & Leaf & Acetone & 6.27 & 16 & 100 & 63.1 & 10.1 & 25.3 & 25.4 \\
\hline BAVARIE1_008 & Kluai Tiparot & Pseudostem & Acetone & 40.3 & - & 60 & 63 & 1.57 & 0.093 & 0.018 \\
\hline BAVARIE1_010 & Petit Naine & Leaf & Acetone & 37.5 & - & 76.8 & $>100$ & $>2.67$ & $>6.4$ & $>2.72$ \\
\hline BAVARIE1_0013 & Cavendish & Leaf & Ethanol & 7.29 & 16.1 & 100 & 44.7 & 6.13 & 19.8 & 15.6 \\
\hline BAVARIE1_0014 & Cavendish & Pseudostem & Ethanol & 46.2 & 89 & 97.1 & $>100$ & $>2.16$ & $>7.89$ & $>2.64$ \\
\hline BAVARIE1_0015 & Cavendish & Corm & Ethanol & 17.8 & - & 65.4 & 63.1 & 3.55 & 4.91 & 2.7 \\
\hline
\end{tabular}


Table 2. Cont.

\begin{tabular}{|c|c|c|c|c|c|c|c|c|c|c|}
\hline Code No. & Variety & Parts Used & $\begin{array}{l}\text { Extract } \\
\text { Tested }\end{array}$ & $\begin{array}{c}E_{50} \\
(\mu \mathrm{g} / \mathrm{mL})\end{array}$ & $\begin{array}{c}\mathrm{EC}_{90} \\
(\mu \mathrm{g} / \mathrm{mL})\end{array}$ & $\begin{array}{l}\text { Maximum \% } \\
\text { Inhibition }\end{array}$ & $\begin{array}{c}\mathrm{CC}_{50} \\
(\mu \mathrm{g} / \mathrm{mL})\end{array}$ & SI & SS & TI \\
\hline BAVARIE1_0016 & Fougamou & Leaf & Ethanol & 10.8 & - & 82.8 & 60.9 & 5.65 & 9.66 & 7.26 \\
\hline BAVARIE1_0017 & Fougamou & Pseudostem & Ethanol & 39.7 & 67 & 100 & $>100$ & $>2.52$ & $>11.6$ & $>4.65$ \\
\hline BAVARIE1_0019 & Mbwazirume & Leaf & Ethanol & 8.41 & 15 & 100 & 44.7 & 5.32 & 18.9 & 13.7 \\
\hline BAVARIE1_0020 & Mbwazirume & Pseudostem & Ethanol & 39 & 67.6 & 92.2 & $>100$ & $>2.56$ & $>10.3$ & $>4.22$ \\
\hline BAVARIE1_0022 & Dole & Leaf & Ethanol & 35 & - & 59.28 & 58.5 & 1.67 & 0.164 & 0.036 \\
\hline BAVARIE1_0023 & Dole & Pseudostem & Ethanol & 39.4 & - & 85.4 & $>100$ & $>2.54$ & $>8.76$ & $>3.55$ \\
\hline BAVARIE1_0024 & Dole & Corm & Ethanol & 37.8 & - & 85.8 & $>100$ & $>2.65$ & $>9.3$ & $>3.93$ \\
\hline BAVARIE1_0025 & Cachaco & Leaf & Ethanol & 8.41 & 15.7 & 91.4 & 50.2 & 5.97 & 17 & 13.2 \\
\hline BAVARIE1_0026 & Cachaco & Pseudostem & Ethanol & 46.5 & - & 82.5 & $>100$ & $>2.15$ & $>6.07$ & $>2.02$ \\
\hline BAVARIE1_0028 & Namwah Khom & Leaf & Ethanol & 10.9 & $>20$ & 79.3 & 54.7 & 5 & 10.2 & 7.17 \\
\hline BAVARIE1_0031 & Saba & Leaf & Ethanol & 13.7 & - & 65.2 & 44.7 & 3.27 & 2.46 & 1.26 \\
\hline BAVARIE1_0034 & Pelipita & Leaf & Ethanol & 7.59 & 13.3 & 92.3 & 72.5 & 9.55 & 21.9 & 21.5 \\
\hline BAVARIE1_0037 & Kluai Tiparot & Leaf & Ethanol & 37.9 & 63.7 & 92.6 & $>100$ & $>2.64$ & $>11$ & $>4.62$ \\
\hline BAVARIE1_0038 & Kluai Tiparot & Pseudostem & Ethanol & 47 & - & 82.5 & $>100$ & $>2.13$ & $>6.01$ & $>1.97$ \\
\hline BAVARIE1_0040 & Petit Naine & Leaf & Ethanol & 34.8 & - & 77.6 & $>100$ & $>2.87$ & $>7.28$ & $>3.33$ \\
\hline BAVARIE1_0043 & Cavendish & Leaf & Acetone & 9.06 & 17.8 & 76.4 & 38.1 & 4.2 & 8.15 & 5.08 \\
\hline BAVARIE1_0044 & Cavendish & Pseudostem & Acetone & 38.4 & - & 85.7 & $>100$ & $>2.6$ & $>9.09$ & $>3.78$ \\
\hline BAVARIE1_0047 & Fougamou & Pseudostem & Acetone & 37.7 & - & 80.6 & $>100$ & $>2.65$ & $>7.93$ & $>3.36$ \\
\hline BAVARIE1_0048 & Fougamou & Corm & Acetone & 8.25 & - & 68.47 & 20 & 2.43 & 3.55 & 1.37 \\
\hline BAVARIE1_0051 & Mbwazirume & Corm & Acetone & 7.47 & 20.0 & 90 & 44.7 & 5.99 & 14.9 & 11.6 \\
\hline BAVARIE1_0053 & Dole & Pseudostem & Acetone & 12.1 & - & 70.72 & 44.7 & 3.69 & 4.41 & 2.5 \\
\hline BAVARIE1_0054 & Dole & Corm & Acetone & 32.2 & - & 74.8 & 100 & 3.11 & 6.1 & 3.01 \\
\hline BAVARIE1_0055 & Cachaco & Leaf & Acetone & 8.56 & 15.9 & 72.6 & 29.9 & 3.49 & 5.64 & 3.06 \\
\hline BAVARIE1_0057 & Cachaco & Corm & Acetone & 36.7 & - & 66.7 & $>100$ & $>2.73$ & $>6.69$ & $>2.92$ \\
\hline BAVARIE1_0058 & Namwah Khom & Leaf & Acetone & 5.94 & 10.4 & 79.86 & 27.6 & 4.65 & 9.67 & 6.45 \\
\hline BAVARIE1_0059 & Namwah Khom & Pseudostem & Acetone & 40.2 & - & 69.91 & 100 & 2.49 & 3.95 & 1.56 \\
\hline BAVARIE1_0100 & Dole & Leaf & Hexane & 43.7 & - & 77.38 & $>100$ & $>2.29$ & $>5.87$ & $>2.11$ \\
\hline Positive control & Favipiravir & - & - & 2.65 & - & - & $>100$ & $>37.7$ & - & - \\
\hline
\end{tabular}

$\mathrm{EC}_{50}=50 \%$ Effective Concentration (concentration at which 50\% inhibition of virus replication is observed); $\mathrm{EC}_{90}=90 \%$ Effective Concentration (concentration at which $90 \%$ inhibition of virus replication is observed); $\mathrm{CC}_{50}=50 \%$ Cytostatic/Cytotoxic Concentration (concentration at which $50 \%$ adverse effect is observed on Vero cells in parallel with antiviral assay); $\mathrm{SI}=$ Selectivity Index $\left(\mathrm{CC}_{50} / \mathrm{EC}_{50}\right)$; $\mathrm{SS}=$ Selectivity Surface (integrated surface delineated by the $\mathrm{EC}_{50}$ curve, the $\mathrm{CC}_{50}$ curve and the $50 \%$ horizontal); $\mathrm{TI}=$ Therapeutic Index $(\mathrm{SS} \times 10 \mathrm{log} \mathrm{SI})$.

(-) Data absent

Both acetone and ethanol extract(s) often exhibited significant antiviral activity, while only one hexane extract was active. With acetone, 19 extracts were active out of 30, while with ethanol 18 out of 30 extracts were active; consequently, both solvents appear equally effective. However, the two solvents do not appear to extract the same bioactive compound. Indeed, for several cultivars and plant parts, the ethanol extract is active, but not the acetone extract, or vice versa. Indeed, there is no significant correlation between the bioactivity of the ethanol versus acetone extracts (Table 2 and Figure 2e). Activity also depended on the plant part; leaf extracts (18 out of 40) were most often effective, followed by pseudostem (12 out of 40) and corm ( 8 out of 40$)$. It could be assumed that if a bioactive compound is produced in one plant part, then the chance is high that it would also be produced in the immediately connecting part of the same plant. Indeed, the bioactivity in leaf is significantly correlated with that of pseudostem, and that of pseudostem with corm (Table 2 and Figure $2 \mathrm{~b}-\mathrm{d}$ ). However, the bioactivity in the corm is not significantly correlated with that of leaf. 

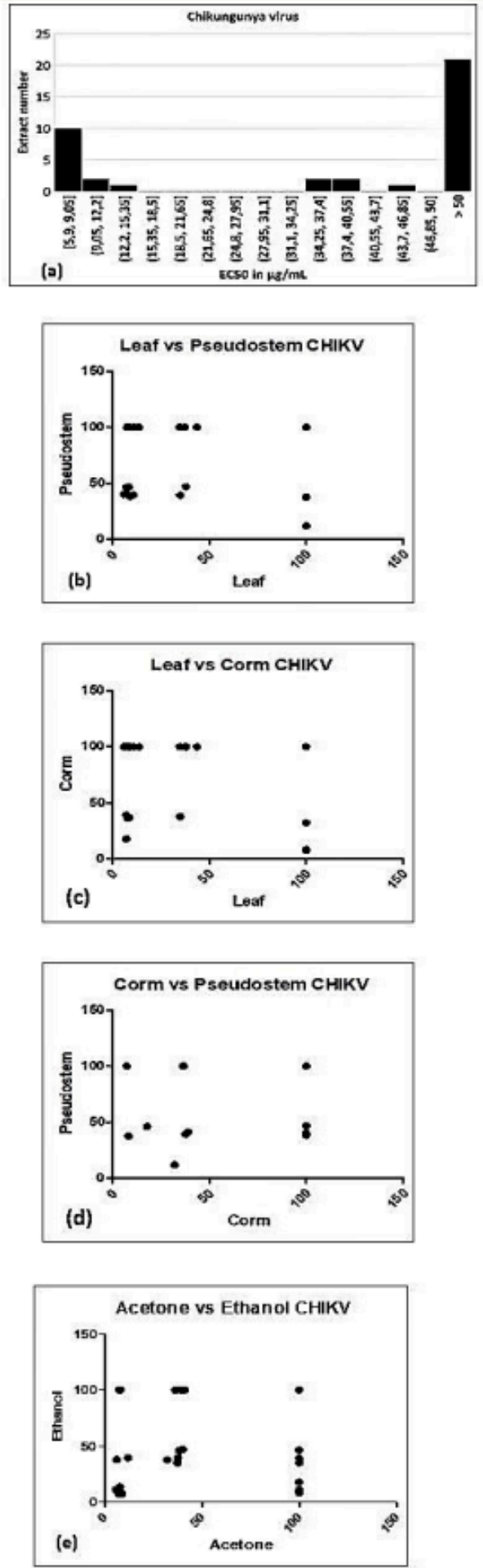
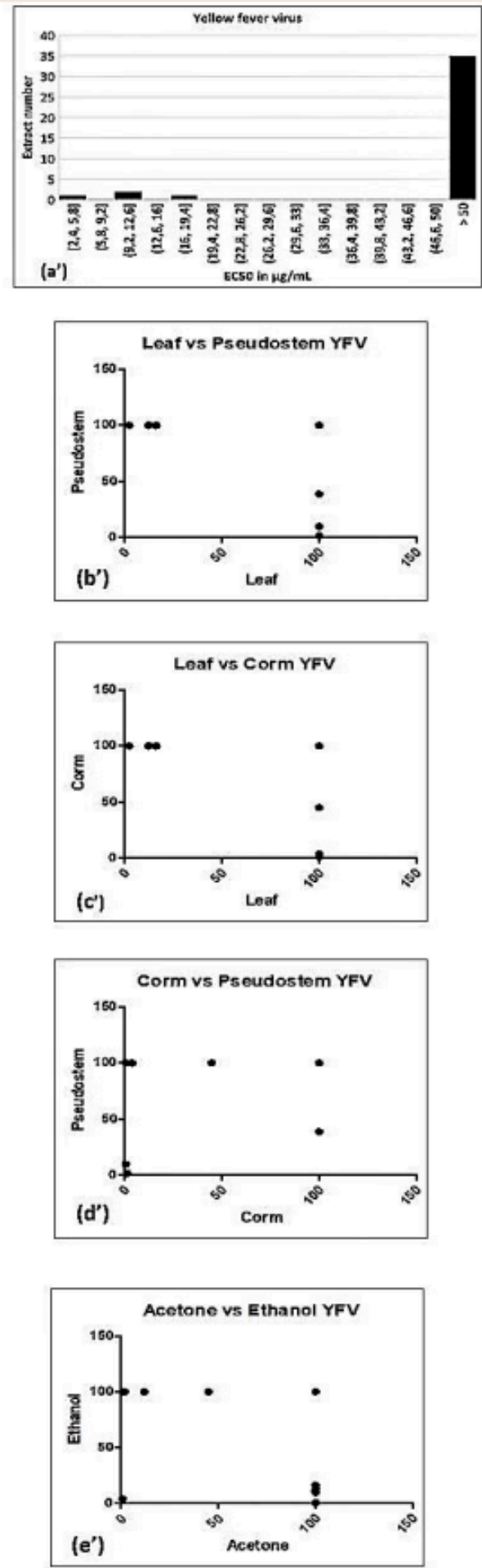

Figure 2. Histogram of $\mathrm{EC}_{50}$ values $\left(\mathbf{a}, \mathbf{a}^{\prime}\right)$, and correlation of bioactivity against Chikungunya virus $(\mathrm{CHIKV})(\mathbf{a}-\mathbf{e})$ or yellow fever virus (YFV) $\left(\mathbf{a}^{\prime}-\mathbf{e}^{\prime}\right)$ between different plant parts $\left(\mathbf{b}-\mathbf{d}, \mathbf{b}^{\prime}-\mathbf{d}^{\prime}\right)$ and different solvents $\left(\mathbf{e}, \mathbf{e}^{\prime}\right)$ used to prepare the extracts.

The relationship between the activities of the different extracts is visualized by a heat map using parameters such as $\mathrm{EC}_{50}, \mathrm{CC}_{50}$, SI, SS, and TI (Figure 3). Cluster 1 (C1) comprises four acetone extracts (leaf extracts from Giant Cavendish, Saba, Cachaco and Fougamou corm) $\left(\mathrm{EC}_{50 \mathrm{~s}} \sim 8.5 \mu \mathrm{g} / \mathrm{mL}\right.$, SI 3.5) and two ethanol extracts from leaves of Namwa Khom and Fougamou $\left(E_{50 \mathrm{~s}}=11 \mu \mathrm{g} / \mathrm{mL}, \mathrm{SI} 5\right)$. The next cluster (C2) is quite similar in antiviral activity but has a somewhat higher cytotoxicity; it 
comprises the ethanol extract from leaves of Saba $\left(\mathrm{EC}_{50}=14 \mu \mathrm{g} / \mathrm{mL}, \mathrm{SI} 3\right)$ and Giant Cavendish corm $\left(\mathrm{EC}_{50}=18 \mu \mathrm{g} / \mathrm{mL}, \mathrm{SI} 3.5\right)$ and the acetone extract from pseudostem of Dole $\left(\mathrm{EC}_{50 \mathrm{~s}}=12 \mu \mathrm{g} / \mathrm{mL}, \mathrm{SI} 4\right)$. The neighbouring cluster (C3) is dominated by acetone extracts from the corm of Dole, Saba, Pelipita, and from the pseudostem of Klue Tiparot, Namwa Khom and Pelipita $\left(E_{50 \mathrm{~s}} 30-40 \mu \mathrm{g} / \mathrm{mL}\right.$, maximum\% of inhibition $\sim 70 \%$ ). Cluster 4 (C4), which is well separated from the other clusters, comprised the largest number of extracts: 14 (9 ethanol +4 acetone +1 hexane), and most extracts (8) are from the pseudostem. This cluster is characterized by high $\mathrm{EC}_{50 \text { s }}$ as well as cytotoxicity. Cluster 5 (C5) has the most interesting antiviral properties due to low $\mathrm{EC}_{50 \mathrm{~s}}$ combined with high $\mathrm{CC}_{50}$. It comprises an ethanol extract from the leaf of Pelipita and the acetone extract of Kluai Tiparot $\left(\mathrm{EC}_{50 \mathrm{~s}}<7 \mu \mathrm{g} / \mathrm{mL}\right.$, SI 10). Cluster 6 (C6) is dominated by leaf parts (ethanol extracts of Giant Cavendish and Cachaco, acetone extracts of Pelipita, Namwa Khom and Mbwazirume). In addition to leaf extracts, this cluster also includes acetone extract from the corm of Mbwazirume. The delineation of this cluster is due to lower $\mathrm{EC}_{50 \mathrm{~s}}(<9 \mu \mathrm{g} / \mathrm{mL})$ with maximum growth inhibition. Extracts showing interesting properties by microscopic examination were assayed again, and this confirmed the first results (Supplementary Material II, Figure S2).

\subsection{Activity of Extracts against YFV}

All extracts were also tested against YFV (Supplementary Material III, Figure S3, Table 3), but far fewer were actively compared to CHIKV. Activity was mostly found in corm extracts (5 out of 40), followed by leaf (4 out of 40) and pseudostem ( 3 out of 40). As with YFV, three clusters of $\mathrm{EC}_{50}$ values were seen, though with different numerical values than for CHIKV (Figure 2a'). Again, the straightforward explanation is that of a single bioactive compound being present at high, low or negligible levels. It could be the same bioactive compound as for CHIKV, whose affinity for the (presumably related) YFV target would be different. Alternatively, two different compounds could be responsible for the bioactivity against these two viruses. The latter seems more likely since the activity on CHIKV and on YFV does not correlate (Spearman rank coefficient $R=0.08708,95 \%$ confidence interval -0.09898 to +0.2672 ).

Table 3. Antiviral and cytotoxic activity of banana varieties against yellow fever virus.

\begin{tabular}{|c|c|c|c|c|c|c|c|c|c|c|}
\hline Code No. & Variety & Parts Used & $\begin{array}{l}\text { Extract } \\
\text { Tested }\end{array}$ & $\begin{array}{c}\mathrm{EC}_{50} \\
(\mu \mathrm{g} / \mathrm{mL})\end{array}$ & $\begin{array}{c}\mathrm{EC}_{90} \\
(\mu \mathrm{g} / \mathrm{mL})\end{array}$ & $\begin{array}{l}\text { Maximum \% } \\
\text { Inhibition }\end{array}$ & $\begin{array}{c}\mathrm{CC}_{50} \\
(\mu \mathrm{g} / \mathrm{mL})\end{array}$ & SI & SS & TI \\
\hline BAVARIE1_001 & Saba & Leaf & Acetone & 12.2 & $>20$ & 64 & 26.2 & 2.14 & 2.27 & 0.75 \\
\hline BAVARIE1_0012 & Petit Naine & Corm & Acetone & 44.8 & 88 & 97.57 & $>100$ & $>2.23$ & $>8.29$ & $>2.89$ \\
\hline BAVARIE1_0013 & Cavendish & Leaf & Ethanol & 12.5 & $>20$ & 52.05 & 13.8 & 1.1 & 0.358 & 0.015 \\
\hline BAVARIE1_0017 & Fougamou & Pseudostem & Ethanol & 1.55 & 2.62 & 75.27 & 5.23 & 3.37 & 6.56 & 3.46 \\
\hline BAVARIE1_0019 & Mbwazirume & Leaf & Ethanol & 16.3 & - & 89.81 & $>100$ & $>6.15$ & $>19.2$ & $>15.1$ \\
\hline BAVARIE1_0029 & Namwah Khom & Pseudostem & Ethanol & 9.77 & - & 89.64 & 90.6 & 9.27 & 19.2 & 18.5 \\
\hline BAVARIE1_0030 & Namwah Khom & Corm & Ethanol & 0.57 & $<0.8$ & 80 & 5.77 & 9.97 & 17.1 & 17 \\
\hline BAVARIE1_0048 & Fougamou & Corm & Acetone & 1.44 & 2.31 & 100 & 76.5 & 53.1 & 63.2 & 109 \\
\hline BAVARIE1_0052 & Dole & Leaf & Acetone & 2.41 & 51.7 & 100 & 6.76 & 2.81 & 29.3 & 13.1 \\
\hline BAVARIE1_0104 & Cachaco & Pseudostem & Hexane & 38.5 & 74.8 & 107 & $>100$ & $>2.6$ & $>11.9$ & $>4.93$ \\
\hline BAVARIE1_0111 & Saba & Corm & Hexane & $<0.8$ & $<0.8$ & 57.4 & 1.12 & $>1.4$ & $>0.54$ & $>0.08$ \\
\hline BAVARIE1_0118 & Fougamou & Corm & Ethanol & 3.84 & $>100$ & 51.31 & 8.94 & 2.33 & 0.241 & 0.088 \\
\hline $\begin{array}{l}\text { Positive } \\
\text { control }\end{array}$ & $2^{\prime}, 5^{\prime}$-bis-O-tri & uridine & - & $1.2 \mu \mathrm{M}$ & - & - & $>100 \mu \mathrm{M}$ & $>80$ & - & - \\
\hline
\end{tabular}

$\mathrm{EC}_{50}=50 \%$ Effective Concentration (concentration at which $50 \%$ inhibition of virus replication is observed); $\mathrm{EC}_{90}=90 \%$ Effective Concentration (concentration at which $90 \%$ inhibition of virus replication is observed); $\mathrm{CC}_{50}=50 \%$ Cytostatic/Cytotoxic Concentration (concentration at which $50 \%$ adverse effect is observed on Huh cells in parallel with antiviral assay; $\mathrm{SI}=$ Selectivity Index $\left(\mathrm{CC}_{50} / \mathrm{EC}_{50}\right)$; SS = Selectivity Surface (integrated surface delineated by the $\mathrm{EC}_{50}$ curve, the $\mathrm{CC}_{50}$ curve and the $50 \%$ horizontal); $\mathrm{TI}=$ Therapeutic Index $(\mathrm{SS} \times 10 \operatorname{logSI})$; (-) Data absent. 


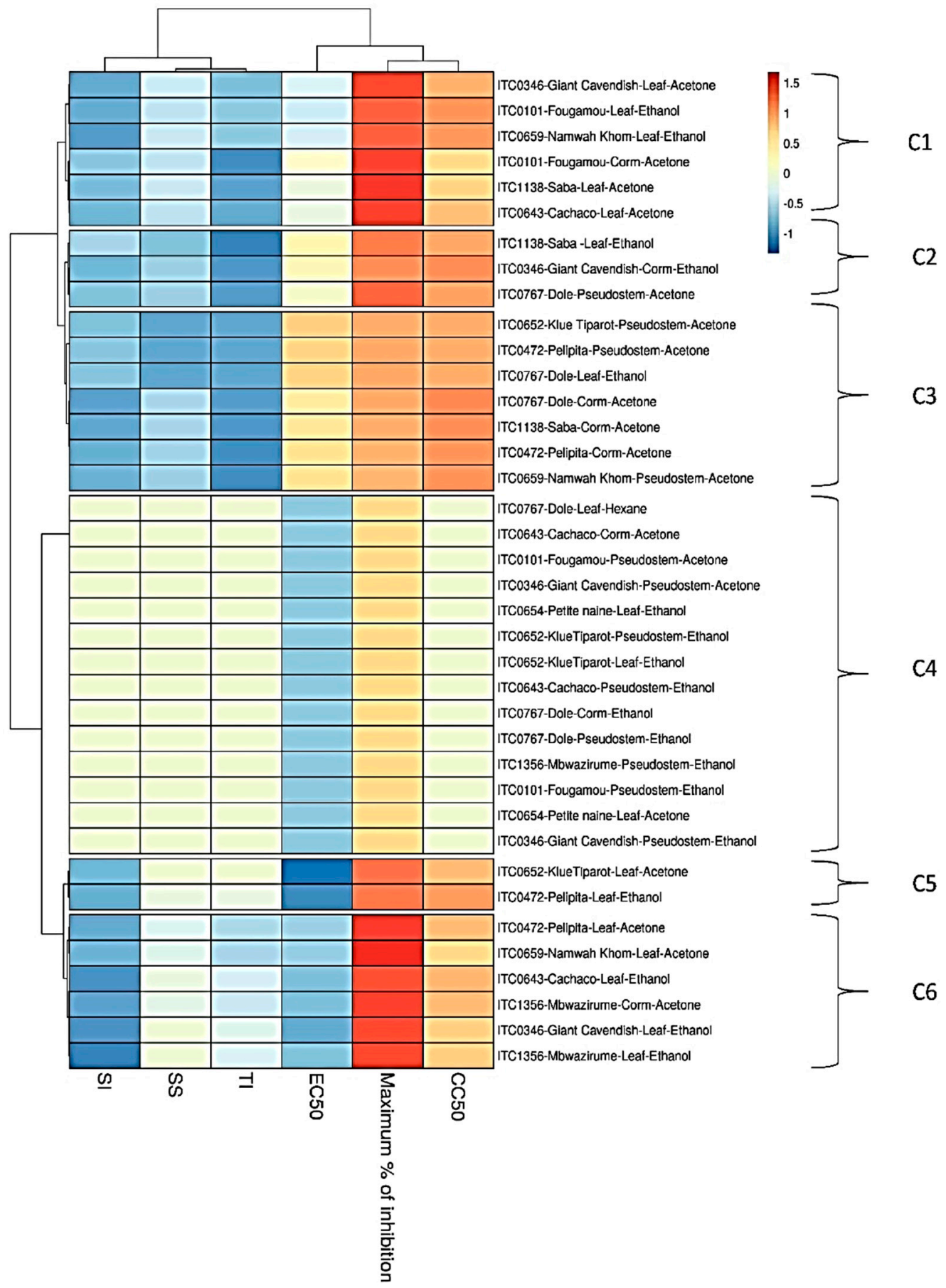

Figure 3. Heat map and clustering of anti-CHIKV activity of extracts from banana cultivars' plant part. $\mathrm{EC}_{50}=50 \%$ Effective Concentration (concentration at which 50\% inhibition of virus replication is observed). $C_{50}=50 \%$ Cytostatic/Cytotoxic Concentration (concentration at which $50 \%$ adverse effect is observed on Vero cells in parallel with antiviral assay). SI = Selectivity Index $\left(\mathrm{CC}_{50} / \mathrm{EC}_{50}\right)$. SS = Selectivity Surface (integrated surface delineated by the $\mathrm{EC}_{50}$ curve, the $\mathrm{CC}_{50}$ curve and the $50 \%$ horizontal). TI = Therapeutic Index (SS $\times 10 \operatorname{logSI})$. C1-C6: different clusters.

Ethanol (6 extracts out of 30) was found to be more effective as a solvent than acetone (4 extracts out of 30) and hexane (2 extracts out of 30) (Supplementary Material III, Figure S3, Table 3). However, as for YFV, bioactivity in ethanol did not correlate with that in acetone (Table 4 and Figure 2e'). For different 
plant parts, activity correlated only between corm and pseudostem (Table 4 and Figure 2d'), although it is difficult to draw strong conclusions since the number of active extracts is rather small.

Table 4. Calculation of nonparametric correlation (Spearman $\mathrm{r}$ ) of $\mathrm{EC}_{50 \mathrm{~s}}$ between different plant parts.

\begin{tabular}{|c|c|c|c|}
\hline Parts & Parameters & CHIKV & YFV \\
\hline \multirow{4}{*}{ Leaf vs. Pseudostem } & Spearman $\mathrm{r}$ & 0.4965 & -0.09467 \\
\hline & $95 \%$ confidence interval & 0.2096 to 0.7046 & -0.4026 to 0.2325 \\
\hline & $P$ value (two-tailed) & 0.0011 & 0.5612 \\
\hline & $\begin{array}{l}\text { Is the correlation significant? } \\
\quad(\text { alpha }=0.05)\end{array}$ & Yes & No \\
\hline \multirow{4}{*}{ Leaf vs. Corm } & Spearman $\mathrm{r}$ & 0.1872 & -0.1392 \\
\hline & $95 \%$ confidence interval & -0.1414 to 0.4787 & -0.4398 to 0.1894 \\
\hline & $P$ value (two-tailed) & 0.2473 & 0.3916 \\
\hline & $\begin{array}{l}\text { Is the correlation significant? } \\
\qquad(\text { alpha }=0.05)\end{array}$ & No & No \\
\hline \multirow{4}{*}{ Corm vs. Pseudostem } & Spearman $\mathrm{r}$ & 0.3755 & 0.4228 \\
\hline & $95 \%$ confidence interval & 0.06294 to 0.6210 & 0.1188 to 0.6544 \\
\hline & $P$ value (two-tailed) & 0.0169 & 0.0066 \\
\hline & $\begin{array}{l}\text { Is the correlation significant? } \\
\quad(\text { alpha }=0.05)\end{array}$ & Yes & Yes \\
\hline \multirow{4}{*}{ Acetone vs. Ethanol } & Spearman $r$ & 0.2695 & 0.0442 \\
\hline & 95\% confidence interval & -0.1117 to 0.5815 & -0.2799 to 0.3593 \\
\hline & $P$ value (two-tailed) & 0.1499 & 0.7863 \\
\hline & $\begin{array}{l}\text { Is the correlation significant? } \\
\quad(\text { alpha }=0.05)\end{array}$ & No & No \\
\hline
\end{tabular}

Extracts that showed prominent antiviral activity are presented in Figure 4 with their $\mathrm{EC}_{50}$ and $\mathrm{CC}_{50}$ values. Like for $\mathrm{CHIKV}$, the two appear not to be correlated. The relationship between the activities of the different extracts is visualized by a heat map using parameters such as $\mathrm{EC}_{50}, \mathrm{CC}_{50}$, maximum \% of inhibition, SI, SS, and TI (Figure 5). The acetone extract of corm of Fougamou represents an isolated cluster $(\mathrm{C} 1)$ due to its low $\mathrm{EC}_{50}(1.4 \mu \mathrm{g} / \mathrm{mL})$ and low cytostatic/cytotoxic effect on Huh cells $\left(\mathrm{CC}_{50}=76.5 \mu \mathrm{g} / \mathrm{mL}\right.$ ) (Supplementary Material III, Figure S3, Table 3, Figure 5). The second cluster (C2) comprises most extracts, ethanol extract of Mbwazirume leaf, Fougamou-pseudostem, Namwa Khom-corm, the acetone extracts of Dole leaf, Petite naine-corm and the hexane extracts Cachaco-pseudostem and Saba-corm. The neighboring cluster (C3) contains one extract i.e., ethanol extract from the pseudostem of Namwa Khom with attractive antiviral properties $\left(\mathrm{EC}_{50}=9 \mu \mathrm{g} / \mathrm{mL}\right.$, $\mathrm{CC}_{50}=90 \mu \mathrm{g} / \mathrm{mL}$ ). The last cluster (C4) contains mostly extracts with strong antiviral activity with maximum inhibition but often accompanied by cytotoxicity. This cluster comprises the ethanol extracts of Fougamou-corm, leaf parts of Giant Cavendish and acetone extract of Saba leaf. Extracts showing interesting properties upon microscopic examination were assayed again, and the results were similar (Supplementary Material III, Figure S3). In summary, the most promising banana cultivars with antiviral properties against YFV are Namwa Khom (ethanol extract from corm and pseudostem) and Fougamou (corm-acetone and pseudostem-ethanol) (Figure 4). 


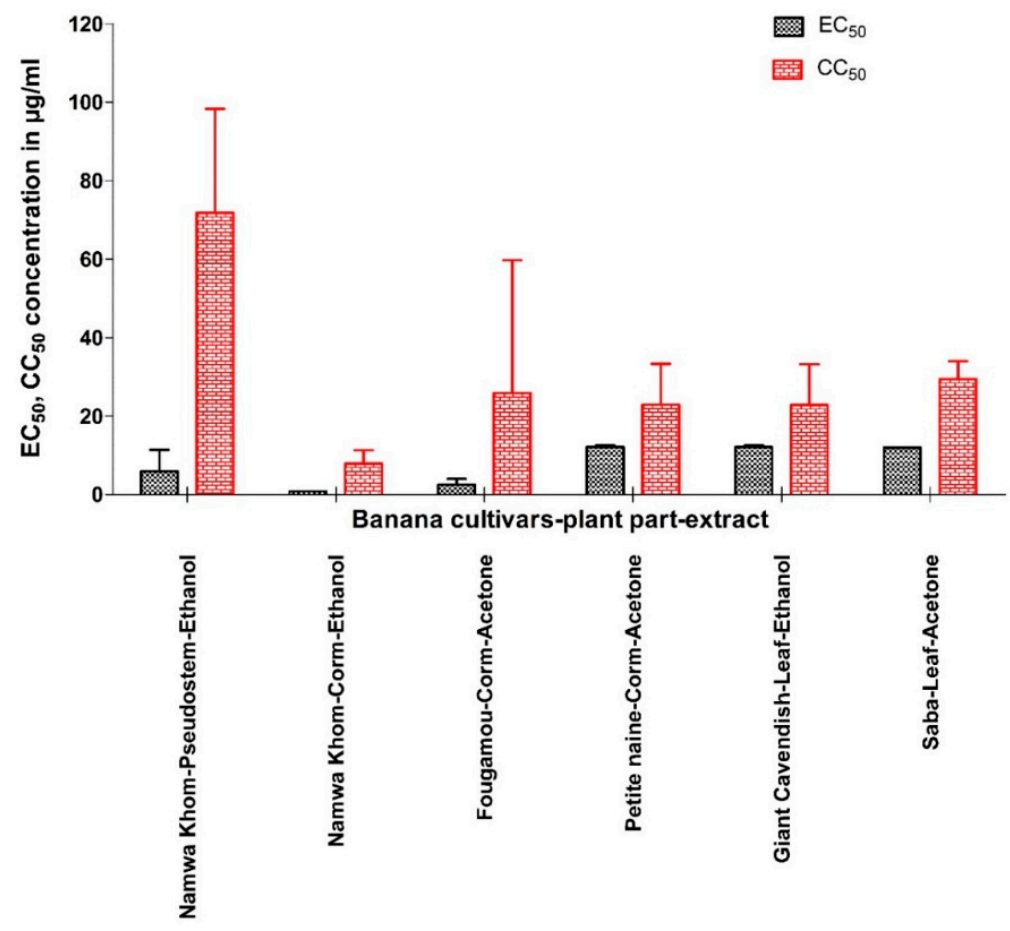

Figure 4. Comparison of $\mathrm{EC}_{50}$ and $\mathrm{CC}_{50}($ mean $\pm \mathrm{SD}$ ) of selected banana cultivars' plant part extract against yellow fever virus.

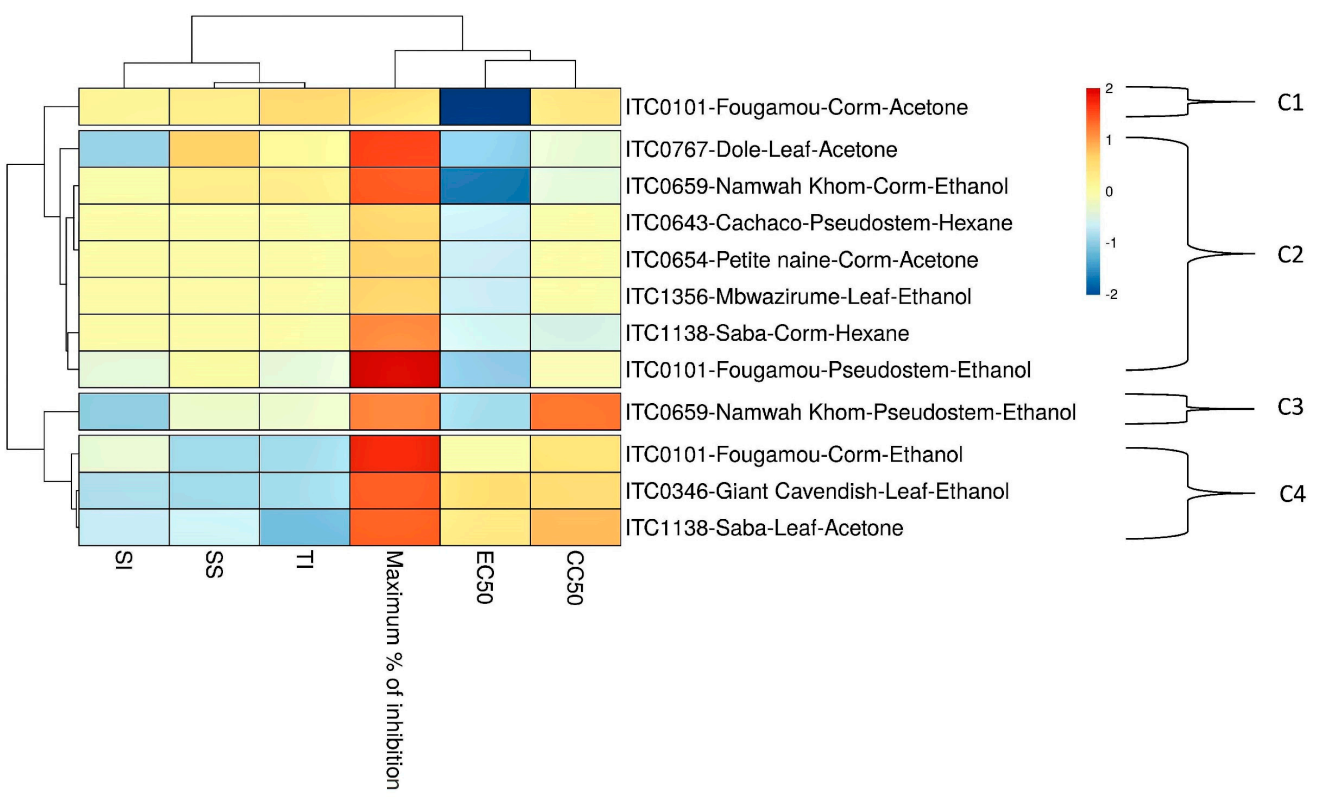

Figure 5. Heat map and clustering of anti-YFV activity of extracts from banana cultivars' plant part. $\mathrm{EC}_{50}=50 \%$ Effective Concentration (concentration at which 50\% inhibition of virus replication is observed). $\mathrm{EC}_{90}=90 \%$ Effective Concentration (concentration at which $90 \%$ inhibition of virus replication is observed). $\mathrm{CC}_{50}=50 \%$ Cytostatic/Cytotoxic Concentration (concentration at which $50 \%$ adverse effect is observed on Huh cells in parallel with antiviral assay). SI = Selectivity Index $\left(\mathrm{CC}_{50} / \mathrm{EC}_{50}\right)$. SS = Selectivity Surface (integrated surface delineated by the $\mathrm{EC}_{50}$ curve, the $\mathrm{CC}_{50}$ curve and the $50 \%$ horizontal $)$. TI $=$ Therapeutic Index $($ SS $\times 10 \operatorname{logSI})$. C1-C4: different clusters. 


\subsection{TLC and TPC}

Using methanol:dichloromethane $(1: 9, v / v)$ as mobile phase, numerous absorbing bands were observed under UV light ( $254 \mathrm{~nm}$ and $360 \mathrm{~nm}$ ) with ethanol extracts. Furthermore, after exposing the plates to $5 \%$ sulphuric acid in ethanol, spots were visualized, and the reaction products were compared under UV light. Interestingly, several extracts show similar fingerprints (observed colour as well as Rf), signifying the presence of similar chemical classes or even compounds. Most of the plant extracts showed brown/dark brown spots at $254 \mathrm{~nm}$, and pink, light pink, or yellow spots at $360 \mathrm{~nm}$ UV, confirming the presence of phenolics and flavonoids, while blue fluorescence indicates saponins and terpenoids (Supplementary Material IV, Figure S4a-c; Table S1ab). Similarly, acetone and hexane extracts were well separated with hexane:ethyl acetate (1:1) as mobile phase but we could not observe as diverse a range of phytoconstituents as in the ethanol extracts; only the presence of phenolics was observed (Supplementary Material IV, Figure S4d-f; Table S1c-d). Interestingly, several extracts show similar fingerprints (observed colour as well as Rf), indicating the presence of similar chemical classes or even compounds, but which of these constitute the bioactive compounds responsible for the detected activities requires further study. Selected extracts were also quantified for their total phenolic content (TPC) from the regression equation of the gallic acid calibration curve $\left(R^{2}=0.9902\right)$, expressed in gallic acid equivalents (GAE) as $\mu \mathrm{g} / \mathrm{mg}$ of the crude extract (Supplementary Material IV, Figure S4g). There is over a 10-fold variation in TPC between extracts in various solvents of different cultivars (24 to $309 \mu \mathrm{g}$ of GAE/mg extracts) (Supplementary Material IV, Table S1e), although most extracts show values between 140 and $198 \mu \mathrm{g}$ of GAE/mg extract. For more information see Supplementary Material IV, Figure S4g and Table S1e. Across all samples, TPC correlates best between the corresponding extracts of leaf versus pseudostem $(r=0.82)$, suggesting that the TPC in most cultivars does not differ very much between plant parts.

\section{Discussion}

Notwithstanding continuous advances made in antiviral therapy, millions of people are still affected by viral diseases. This may lead to death in severe cases, especially if no drug treatment is available. Even when effective antiviral drugs exist, treatment may not be successful due to the emergence of resistant strains. Viral replication is largely dependent on the host cell (the virus acts as an intracellular parasite). Therefore, it is difficult to find an effective antiviral compound that acts only on the virus without affecting the host cell. This has been achieved for viruses with essential enzymes absent in the host (like reverse transcriptase), or with viral enzymes sufficiently different from the host orthologues (like some protease inhibitors).

Many currently used antiviral drugs are expensive and have side effects. Hence, it is interesting to look for novel sources of antiviral compounds. Because of prior reports of activity against HIV in banana plants, we tested the antiviral properties of banana extracts as a potential source of novel antiviral drugs.

CHIKV is one of the re-emerging vector-borne viral diseases and considered as a neglected tropical disease, mainly because the affected regions are in Africa and Southeast Asia. CHIKV is transmitted to humans by infected mosquitoes, and there is at present no cure for this disease (https://www.who.int/news-room/fact-sheets/detail/chikungunya). It causes fever and severe joint pains. Moreover, there are no currently approved vaccines or antiviral treatments available yet for the prevention or treatment of CHIKV infection; it is therefore important to search for new bioactive molecules.

Similarly, another important viral disease (yellow fever) is an acute viral haemorrhagic disease transmitted by mosquitos. The virus is endemic to tropical areas of Africa and Central and South America. There is currently no specific antiviral drug for yellow fever. It can be prevented by vaccination, but due to poor coverage of vaccination in Africa, there are threats of re-emergence in its endemic habitat, and new drugs are urgently needed. 
Enterovirus 71 infections can cause mild hand, foot and mouth disease, but also lead (more rarely) to severe fatal neurological complications. Vaccines have been developed in China, but are not used population-wide due to concerns about side-effects. Antiviral drugs would therefore be welcome.

Banana (Ensete superbum Roxb., Cheesman, Family: Musaceae), is commonly used by Indian tribes for treating measles (Nandurbar district, state-Maharashtra, India) as well as for chickenpox (tribes of Dang district, state-Gujrat, India [27,28]. However, there is no scientific evidence that this banana has antiviral properties except for one study [29]. A lectin (BanLec) from Musa acuminata was found to be a potent inhibitor of HIV replication $[16,17]$. Therefore, in the present study, we systematically tested different parts of 10 banana cultivars for antiviral activity. We did not find any prior reports on antiviral activity against YFV, CHIKV or EV71.

In the cluster analysis for both viruses, the antiviral parameters cluster in the same way. SS, SI and TI cluster very tightly together, which is not surprising since they all describe aspects of the therapeutic window. Logically, $\mathrm{EC}_{50}$ and maximum \% inhibition also correlate well, since both reflect viral inhibition. Neither correlate well with $\mathrm{CC}_{50}$, which stands to reason since antiviral and cytotoxic effects presumably have different mechanisms.

Although some solvents (ethanol, acetone) extract active compounds much more often than others (hexane, water) in our study, this cannot necessarily be generalized to other plants or other bioactivities. It does suggest that our bioactive compounds are not very hydrophobic nor strongly hydrophilic. Not only does the solubility in acetone and ethanol differ for most chemicals, but the fact that the two solvents give different activity results for many plant samples indicates that they probably do not extract the same compounds.

In the present study, phytochemical analysis of different extracts revealed the presence of flavonoids, saponins and terpenoids. Fahim et al. recently investigated the phytochemical spectrum from fruits of $M$. x paradisiaca oils from different geographical areas of India. They found an intense peak with similar Rf value in the TLC $(0.55,0.68,0.81,0.94)$. Phenolic compounds, such as caffeic acid, ferulic acid, catecholamines, flavanones, flavanols, and tocopherols were reported in banana previously [30,31]. Several phenolic compounds are well known for their antiviral activity [32,33].

We also estimated TPC in a number of our crude extracts (Supplementary Material IV, Table S1e). There is a more than 20-fold difference in TPC among extracts, and even the extract with the lowest TPC i.e., Fougamou-leaf-ethanol ( $24 \mu \mathrm{g}$ of GAE/mg extract) showed strong anti-CHIKV activity $\left(\mathrm{EC}_{50 \mathrm{~s}}=10.8 \mu \mathrm{g} / \mathrm{mL}, \mathrm{SI} \sim 5.65, \mathrm{SS}=9.66, \mathrm{TI}=7.26\right)$. This does not preclude that a specific phenolic compound may contribute to the observed activity. Aquino et al. also observed variation among the different plant parts, but not so much among the cultivars, viz., TPC among 15 cultivars ranged from 23.15 to $33.28 \mathrm{mg} / 100 \mathrm{gm}$ GAE for unripe pulp, 42.4 to $77.07 \mathrm{mg} / 100 \mathrm{gm}$ GAE for ripe pulp, 32 to $61 \mathrm{mg} / 100 \mathrm{gm}$ GAE for unripe peel, and 60.39 to $115.7 \mathrm{mg} / 100 \mathrm{gm}$ GAE for ripe peel [34]. We find typical values of $160 \mu \mathrm{g} / \mathrm{mg}$ GAE in our crude extracts. Since the yields of the crude extracts are typically $25-75 \mathrm{mg} / \mathrm{g}$ dried plant material for the organic solvents, and the weight loss upon drying is typically $90 \%$, this means $40-120 \mathrm{mg} / 100 \mathrm{~g}$ original plant material. These TPC values are in the same range as those reported in the literature. Although the concentration of metabolites may differ considerably between plant parts, it is reasonable to assume that the presence of a bioactive compound in one plant part of a cultivar renders it more likely that it is also present in neighboring parts of the same cultivar.

Assuming that the metabolomes of two plant cultivars will resemble each other more the closer the cultivars are related genetically; we expect a correlation between the bioactivities of cultivars and their genetic relatedness. Therefore, a dendrogram was constructed based on DNA sequence data from the tested cultivars, using the unweighted pair group method with arithmetic mean (UPGMA) [26]. This cladogram mainly distributed into two main clades, corresponding to karyotypes AAA and ABB (Figure 6). The ABB clade is nicely correlated with activity, and the cultivars with genome ABB were typically found to have anti-CHIKV activity. 


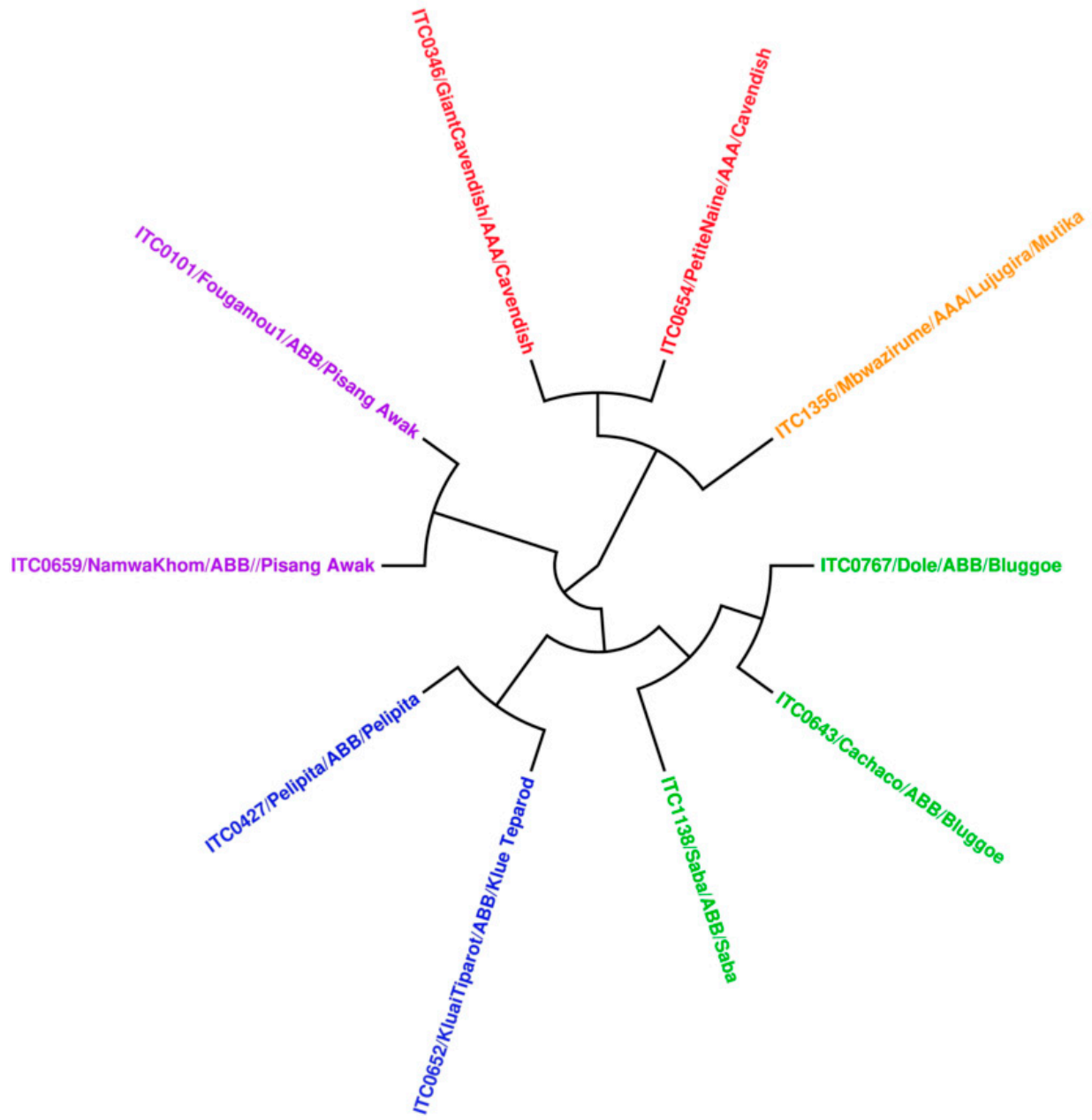

Figure 6. Construction of UPGMA dendrogram using all tested cultivars.

Two banana cultivars showed interesting antiviral activity against YFV: ethanol extracts from pseudostem of the very close genetically-related Fougamou and Namwa Khom (genome ABB) (Figure 6). Three other cultivars (Saba-leaf-acetone, Petite naine-corm-acetone, Giant Cavendish-corm-ethanol) were also found to be effective, but they are also cytotoxic for Huh cells. Therefore, also for YFV, potent antiviral activity is found in some cultivars with genome $A B B$, but no activity in cultivars with genome AAA (Giant Cavendish, Mbwazirume and Petite naine). All extracts were tested on EV71, but none inhibited the infection of RD host cells by EV 71 .

The crude extracts that we tested are complex mixtures, where individual compounds or combinations thereof can contribute to the antiviral effect. Given that we tested crude extracts, the $\mathrm{EC}_{50}$ values are quite impressive for certain cultivars compared to previous studies with medicinal plants [21,35]. The results of the present study establish a base to start bioassay-guided purification to identify the active compounds responsible for the antiviral activity.

\section{Conclusions}

In conclusion, the present results demonstrate that the genetically closely-related banana cultivars with genome ABB such as Namwa Khom, Pelipita, Fougamou and Kluai Tiparot are potential sources for developing antiviral drugs against CHIKV, while Namwa Khom and Fougamou cultivars can provide antiviral compounds against YFV. 
Supplementary Materials: The following are available online at http://www.mdpi.com/1999-4915/12/5/549/s1, Figure S1: Antiviral activity of extracts against enterovirus; Figure S2: Antiviral activity of extracts against Chikungunya virus; Figure S3: Antiviral activity of extracts against yellow fever virus; Figures S4a-f: TLC of selected extracts (acetone, ethanol, hexane); Figure S4g: Regression curve for gallic acid assayed with the Folin-Ciocalteu reagent. Figures S4h: Distribution of total phenolic content across all samples analysed. Table S1a-d: Rf value of TLC (acetone, ethanol, hexane extracts) Table S1e: Total phenolic content (gallic acid equivalents, $\mu \mathrm{g} / \mathrm{mg}$ ) of different extracts.

Author Contributions: Conceived and designed the experiments: S.K.P., P.L., W.L.; Performed the experiments: P.L.; Analyzed the data: A.H.F.C., R.S.J., S.K.P.; Contributed reagents/materials/analysis tools: J.N., R.S., W.L.; Contributed to the writing of the manuscript: S.K.P.; Revision of the manuscript: R.S., W.L. All authors have read and agreed to the published version of the manuscript.

Funding: This research was funded by a postdoctoral scholarship of the National Council for Scientific and Technological Development (CNPq) (Ana Hortência Fonsêca Castro), R. Jouneghani and W. Luyten largely supported themselves. The authors thank all donors who supported this work through their contributions to the CGIAR Fund (http://www.cgiar.org/who-we-are/cgiar-fund/fund-donors-2/), and in particular to the CGIAR Research Program Roots, Tubers and Bananas (RTB-CRP).

Acknowledgments: We thank Ewaut Kissel, Lut Ooms and Edwige André (KU Leuven, Belgium) and Michael Batte (International Institute of Tropical Agriculture) for assisting in the collection and drying of plant materials. We are grateful for the genetic relationship analyses carried out by Eva Hřibová and Doležel Jaroslav (Institute of Experimental Botany, Czech Academy of Sciences, Centre of the Region Hana for Biotechnological and Agricultural Research, Czech Republic). Thanks also to Purity Ngina Kipanga, Bishnu Joshi, Maoxuan Liu and Yipeng Ma (KU Leuven), for their technical help during experimental work. We are thankful to Dirk Jochmans (KU Leuven) for help with the final redaction of the manuscript.

Conflicts of Interest: The authors declare no conflict of interest. The funders had no role in the design of the study; in the collection, analyses, or interpretation of data; in the writing of the manuscript, or in the decision to publish the results.

\section{References}

1. Food and Agriculture Organization of the United Nations. Banana Market Review Preliminary Results for 2018, Rome, Italy, 2018. Available online: www.fao.org/fileadmin/templates/est/COMM_MARKETS_MONITORING/ Bananas/Documents/Banana_Market_Review_Prelim_Results_2018.pdf (accessed on 13 May 2020).

2. Heslop-Harrison, J.S.; Schwarzacher, T. Domestication, Genomics and the Future for Banana. Ann. Bot. 2007, 100, 1073-1084. [CrossRef] [PubMed]

3. Swennen, R.; Rosales, F. Bananas. In Encyclopedia of Agricultural Science; Academic Press: New York, NY, USA, 1994.

4. Wuyts, N.; Swennen, R.; De Waele, D. Activity of phenylalanine ammonia-lyase, peroxidase and polyphenol oxidase in roots of banana (Musa acuminata AAA, cvs Grande Naine and Yangambi km5) before and after infection with Radopholus similis. Nematology 2006, 8, 201-209. [CrossRef]

5. Amah, D.; Alamu, E.; Adesokan, M.; van Biljon, A.; Maziya-dixon, B.; Swennen, R.; Labuschagne, M. Variability of carotenoids in a Musa germplasm collection and implications for provitamin A biofortification. Food Chem. X 2019, 2, 100024. [CrossRef]

6. Amah, D.; van Biljon, A.; Brown, A.; Perkins-Veazie, P.; Swennen, R.; Labuschagne, M. Recent advances in banana (Musa spp.) biofortification to alleviate vitamin A deficiency. Crit. Rev. Food Sci. Nutr. 2018, 59, 3498-3510. [CrossRef]

7. Singh, B.; Singh, J.P.; Kaur, A.; Singh, N. Bioactive compounds in banana and their associated health benefits-A review. Food Chem. 2016, 206, 1-11. [CrossRef] [PubMed]

8. Pereira, A.; Maraschin, M. Banana (Musa spp.) from peel to pulp: Ethnopharmacology, source of bioactive compounds and its relevance for human health. J. Ethnopharmacol. 2015, 160, 149-163. [CrossRef] [PubMed]

9. Passo Tsamo, C.V.; Herent, M.-F.; Tomekpe, K.; Happi Emaga, T.; Quetin-Leclercq, J.; Rogez, H.; Larondelle, Y.; Andre, C.M. Effect of boiling on phenolic profiles determined using HPLC/ESI-LTQ-Orbitrap-MS, physico-chemical parameters of six plantain banana cultivars (Musa sp). J. Food Compos. Anal. 2015, 44, 158-169. [CrossRef]

10. Panda, S.K.; Patra, N.; Sahoo, G.; Bastia, A.K.; Dutta, S.K. Anti-Diarrheal Activities of Medicinal Plants of Similipal Biosphere Reserve, Odisha, India. Int. J. Med. Aromat. Plants 2012, 2, 123-134.

11. Panda, S.K.; Brahma, S.; Dutta, S.K. Selective antifungal action of crude extracts of Cassia fistula L.: A preliminary study on Candida and Aspergillus species. Malays. J. Microbiol. 2010, 6, 62-68. 
12. Goel, R.K.; Sairam, K. Anti-ulcer drugs from indigenous sources with emphasis on Musa sapientum, tamrabhasma, Asparagus racemosus and Zingiber officinale. Indian J. Pharmacol. 2002, 34, 100-110.

13. Gomathy, R.; Vijayalekshmi, N.R.; Kurup, P.A. Hypolipidemic principle of the inflorescence stalk of plantain (Musa sapientum). J. Biosci. 1989, 14, 301-309. [CrossRef]

14. Gomathy, R.; Vijayalekshmi, N.R.; Kurup, P.A. Hypoglycemic action of the pectin present in the juice of the inflorescence stalk of plantain (Musa sapientum)—Mechanism of action. J. Biosci. 1990, 15, 297-303. [CrossRef]

15. Agarwal, P.K.; Singh, A.; Gaurav, K.; Goel, S.; Khanna, H.D.; Goel, R.K. Evaluation of wound healing activity of extracts of plantain banana (Musa sapientum var. paradisiaca) in rats. Indian J. Exp Biol. 2009, 47, 32-40. [PubMed]

16. Swanson, M.D.; Winter, H.C.; Goldstein, I.J.; Markovitz, D.M. A lectin isolated from bananas is a potent inhibitor of HIV replication. J. Biol. Chem. 2010, 285, 8646-8655. [CrossRef] [PubMed]

17. Swanson, M.D.; Boudreaux, D.M.; Salmon, L.; Chugh, J.; Winter, H.C.; Meagher, J.L.; André, S.; Murphy, P.V.; Oscarson, S.; Roy, R.; et al. Engineering a Therapeutic Lectin by Uncoupling Mitogenicity from Antiviral Activity. Cell 2015, 163, 746-758. [CrossRef]

18. Risterucci, A.M.; Hippolyte, I.; Perrier, X.; Xia, L.; Caig, V.; Evers, M.; Huttner, E.; Kilian, A.; Glaszmann, J.C. Development and assessment of Diversity Arrays Technology for high-throughput DNA analyses in Musa. Theor. Appl. Genet. 2009, 119, 1093-1103. [CrossRef]

19. Panda, S.K. Ethno-medicinal uses and screening of plants for antibacterial activity from Similipal Biosphere Reserve, Odisha, India. J. Ethnopharmacol. 2014, 151, 158-175. [CrossRef]

20. Panda, S.K.; Padhi, L.; Leyssen, P.; Liu, M.; Neyts, J.; Luyten, W. Antimicrobial, anthelmintic, and antiviral activity of plants traditionally used for treating infectious disease in the Similipal Biosphere Reserve, Odisha, India. Front. Pharmacol. 2017, 8, 658. [CrossRef]

21. Ledoux, A.; Cao, M.; Jansen, O.; Mamede, L.; Campos, P.-E.; Payet, B.; Clerc, P.; Grondin, I.; Girard-Valenciennes, E.; Hermann, T.; et al. Antiplasmodial, anti-chikungunya virus and antioxidant activities of 64 endemic plants from the Mascarene Islands. Int. J. Antimicrob. Agents 2018, 52, 622-628. [CrossRef]

22. Saudi, M.; Zmurko, J.; Kaptein, S.; Rozenski, J.; Neyts, J.; Van Aerschot, A. Synthesis and evaluation of imidazole-4,5-and pyrazine-2,3-dicarboxamides targeting dengue and yellow fever virus. Eur. J. Med. Chem. 2014, 87, 529-539. [CrossRef]

23. Panda, S.K.; Mohanta, Y.K.; Padhi, L.; Luyten, W. Antimicrobial activity of select edible plants from Odisha, India against food-borne pathogens. LWT 2019, 113, 108246. [CrossRef]

24. Jouneghani, R.S.; Castro, A.H.F.; Panda, S.K.; Swennen, R.; Luyten, W. Antimicrobial Activity of Selected Banana Cultivars Against Important Human Pathogens, Including Candida Biofilm. Foods 2020, 9, 435. [CrossRef] [PubMed]

25. Michener, C.D.; Sokal, R.R. A Quantitative Approach to A Problem in Classification. Evolution 1957, 11, 130-162. [CrossRef]

26. Christelová, P.; De Langhe, E.; Hřibová, E.; Č́ižková, J.; Sardos, J.; Hušáková, M.; Van den houwe, I.; Sutanto, A.; Kepler, A.K.; Swennen, R.; et al. Molecular and cytological characterization of the global Musa germplasm collection provides insights into the treasure of banana diversity. Biodivers. Conserv. 2017, 26, 801-824. [CrossRef]

27. Patil, H.M.; Bhaskar, V.V. Medicinal knowledge system of tribals of Nandurbar district, Maharashtra. Indian J. Tradit. Knowl. 2006, 5, 327-330.

28. Kumar, V. Ethno-medicinal plants in five forest ranges in Dang's district, South Gujarat, India. Ann. Pharm. Pharm. Sci. 2015, 6, 33-42.

29. Dutta, N.K.; Dave, K.H.; Desal, S.M.; Mhasalkar, M.Y. Anti-variola and anti-vaccinia principles from seeds of Banakadali (Ensete superbum Cheesm, Musaceae). Indian J. Med. Res. 1968, 56, 735-741.

30. Corona, M.A.; Gómez-Patiño, M.B.; de Flores, M.J.; Ruiz, L.A.; Martinez, B.M.; Arrieta-Baez, D. An Integrated Analysis of the Musa Paradisiaca Peel, Using UHPLC-ESI, FT-IR and Confocal Microscopy Techniques. Ann. Chromatogr. Sep. Tech. 2015, 1, 1005.

31. Someya, S.; Yoshiki, Y.; Okubo, K. Antioxidant compounds from bananas (Musa Cavendish). Food Chem. 2002, 79, 351-354. [CrossRef] 
32. Medini, F.; Megdiche, W.; Mshvildadze, V.; Pichette, A.; Legault, J.; St-Gelais, A.; Ksouri, R. Antiviral-guided fractionation and isolation of phenolic compounds from Limonium densiflorum hydroalcoholic extract. Comptes Rendus Chim. 2016, 19, 726-732. [CrossRef]

33. Petrescu, A.M.; Paunescu, V.; Ilia, G. The antiviral activity and cytotoxicity of 15 natural phenolic compounds with previously demonstrated antifungal activity. J. Environ. Sci. Health. Part B Pestic. Food Contam. Agric. Wastes 2019, 54, 498-504. [CrossRef] [PubMed]

34. Aquino, C.F.; Salomão, L.C.C.; Ribeiro, S.M.R.; De Siqueira, D.L.; Cecon, P.R. Carboidratos, compostos fenólicos e atividade antioxidante em polpas e cascas de 15 cultivares de bananeira. Rev. Bras. Frutic. 2016, 38. [CrossRef]

35. Panda, S.K.; Das, R.; Leyssen, P.; Neyts, J.; Luyten, W. Assessing medicinal plants traditionally used in the Chirang Reserve Forest, Northeast India for antimicrobial activity. J. Ethnopharmacol. 2018, 225, 220-233. [CrossRef] [PubMed]

(C) 2020 by the authors. Licensee MDPI, Basel, Switzerland. This article is an open access article distributed under the terms and conditions of the Creative Commons Attribution (CC BY) license (http://creativecommons.org/licenses/by/4.0/). 